„Kwartalnik Filmowy” nr 115 (2021)

ISSN: 0452-9502 (Print) ISSN: 2719-2725 (Online)

https://doi.org/10.36744/kf.859

(c) Creative Commons BY-NC-ND 4.0

Teresa Rutkowska

Instytut Sztuki, Polska Akademia Nauk

https://orcid.org/oooo-0002-2888-9206

\title{
Transnarodowe i narodowe szlaki kina nordyckiego
}

\author{
Slowa kluczowe: \\ kino skandynawskie; \\ Ingmar Bergman; \\ Jan Troell; \\ historia filmu
}

\begin{abstract}
Abstrakt
Tadeusz Szczepański, znawca kina skandynawskiego, autor obszernej monografii Ingmara Bergmana i książki o Janie Troellu, wydał obecnie historyczną pracę Kino nordyckie. Pierresze stulecie (2020), która obejmuje czasy od kina niemego przez okres klasyczny i kino nowej fali po koniec XX w. Ujęcie to uwzględnia złożony fenomen kulturowy, jakim jest kino powstające w pięciu krajach: Szwecji, Danii, Norwegii, Finlandii oraz Islandii. Autor wyodrębnia cechy wspólne, ale także specyfikę narodową cechującą poszczególne kinematografie nordyckie. Postacią kluczową jest w tym wywodzie Ingmar Bergman, jego twórczość, a także wpływ, jaki wywarł na kino tego regionu.
\end{abstract}



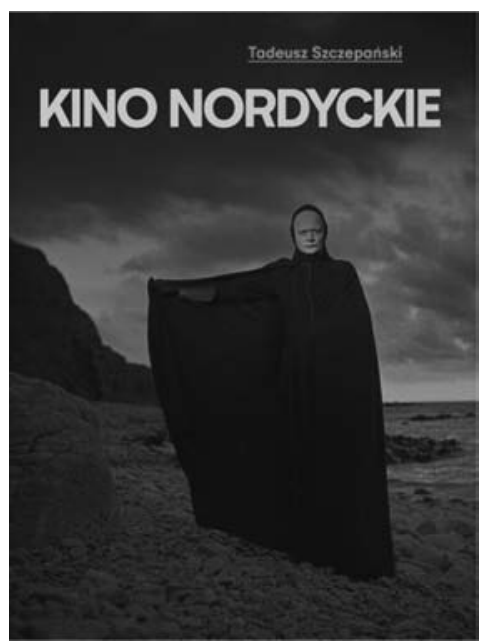

Fenomen kina nordyckiego czy skandynawskiego jest w kontekście kultury europejskiej bardziej złożony i niejednoznaczny, niż wydaje się na pierwszy rzut oka. Region obejmuje pięć państw narodowych: Szwecję, Danię, Norwegię, Finlandię i Islandię, w tym cztery terytoria: Laponię, Grenlandię (terytorium zależne Danii, niebędące członkiem Unii Europejskiej, które od 2009 r. poszerzyło znacznie swoją autonomię), Wyspy Owcze (również niezrzeszone z Unią terytorium zależne Danii) oraz Wyspy Alandzkie (będące jednostką administracyjną Finlandii, jednak szwedzkojęzyczne). Ten konglomerat geograficzny, polityczny i kulturowy ma wiele czynników wspólnych (u ich podłoża leżą zarówno warunki naturalne, jak i perturbacje dziejowe), ale także sporo istotnych różnic, sprzyjających kultywowaniu odrębności i swoistości narodowej. Nie bez znaczenia jest też wielorakość języków ${ }^{1}$. Szwedzki, duński i norweski mają cechy podobne, co umożliwia wzajemne zrozumienie, w ograniczonym wprawdzie zakresie, ale już lapoński i fiński nie należą do języków indoeuropejskich, tylko ugrofińskich, a grenlandzki do grupy eskimo-aleuckiej. W dodatku współczesny islandzki i lapoński mają wiele cech wywodzących się ze staronordyjskiego języka Wikingów. Międzynarodowy Instytut Filmów Lapońskich (ISFI) z siedzibą w Finlandii promuje filmy realizowane w języku lapońskim zdecydowanie ponad granicami państwowymi. Paradoksalnie, skandynawskim językiem wspólnotowym stał się więc w pewnym sensie angielski. Wszystkie wspomniane komplikacje i swoistości rzutują na artystyczny pejzaż tej części Europy, w tym także na kino. Przy tym z tych stosunkowo niewielkich kinematografii wywodzą się twórcy o kluczowym znaczeniu dla historii filmu światowego. A równocześnie świadomość znaczenia kina dla umacniania tożsamości narodowej pojawiła się tu bardzo wcześnie i do dziś nie straciła na znaczeniu, zwłaszcza jeśli chodzi o rolę mecenatu państwowego w odniesieniu do wspomnianych mniejszości etnicznych.

W filmoznawstwie ścierają się dwie tendencje - jedna kładzie nacisk na eksponowanie różnic narodowych, druga na kategorię transnarodowości. Jon Woronoff, redaktor Historical Dictionary of Scandinavian Cinema (2012) ${ }^{2}$, twierdzi we wstępie do tej publikacji, że zjawisko takie jak kino skandynawskie w ogóle nie istnieje i należy mówić zdecydowanie o kinie pięciu różnych krajów skandynawskich. Autorzy A Companion to Nordic Cinema (2016) chętniej wskazują na cechy łączące twórczość filmową północy Europy.

Tadeusz Szczepański, najwybitniejszy w Polsce znawca tego kina, świadom trudności klasyfikacyjnych i interpretacyjnych, szuka rozwiązania kompromisowego, by nakreślić obraz w miarę wszechstronny, mając przy tym na uwadze wyjątkowość i rangę najważniejszych jego przedstawicieli. Książka Kino nordyckie. Pierwsze stulecie zawiera w zasadzie teksty drukowane wcześniej w czterech tomach Historii kina (doprowadzonej do końca XX w.) wydawanych przez Tadeusza Lubelskiego, Iwonę Sowińską i Rafała Syskę w latach 2010-2019. Kino nordyckie zachowuje więc pierwotną strukturę wywodu, z tradycyjnym podziałem na kina na- 
rodowe (szwedzkie, duńskie, norweskie, fińskie, w ostatniej części także islandzkie) i z uwzględnieniem takich uwarunkowań jak kontekst historyczny, sytuacja ekonomiczna i polityczna, rozwój technologii oraz systemy producenckie i instytucjonalne. Zgodnie z formułą Historii kina autor dąży do syntetycznego problematyzowania zagadnień, przy nieco szerszym omówieniu filmów i drogi artystycznej najbardziej znaczących twórców. Książkę zamyka kalendarium tej kinematografii, wskazanie lektur, wreszcie skorowidz nazwisk i tytułów. Został zachowany podział na cztery epoki (w Historii kina odpowiada to tytułom czterech tomów): kino nieme, kino klasyczne, kino epoki nowofalowej i kino końca stulecia. Uwagę zwraca staranna, atrakcyjna szata graficzna i liczne, ciekawe ilustracje.

Zebranie dziejów tego kina w jednym tomie zmienia nieco perspektywę czytelniczą. Kinematografię skandynawską postrzegamy tu już nie tyle w układzie poziomym, jako część tendencji ogólnoświatowej, ile przede wszystkim w jej rozwoju historycznym od początków po czasy współczesne, z naciskiem na specyfikę zjawiska. Dlatego też po książkę sięgną zapewne chętnie odbiorcy zainteresowani tym właśnie kinem i pojętą szerzej, kulturą nordycką. Jest ich coraz więcej, zwłaszcza że pewne istotne zjawiska, jak transnarodowa twórczość Bille Augusta i Larsa von Triera czy idea Dogmy 95, zyskały nadspodziewanie szeroki i trwały rezonans, a współczesna tendencja jest taka, by poszukiwać inspiracji artystycznej i intelektualnej poza globalnym Hollywood, w kinematografiach dotychczas niedocenianych. Ta problematyka weszła też w obręb studiów uniwersyteckich, zarówno w Skandynawii, jak i na całym świecie.

Dzieje skandynawskiego kina niemego rozpoczęły się podobnie jak w całej Europie u schyłku XIX w. Szczepański zwraca jednak uwagę, że filmowy impuls artystyczny był tu nadspodziewanie silny jak na stosunkowo niewielką populację na tych obszarach i ograniczony w porównaniu z bogatszymi krajami potencjał gospodarczy. Pierwszym państwem skandynawskim, którego filmy wzbudziły zainteresowanie za granica, była Dania, a sprzyjała temu popularność jednej z pierwszych gwiazd srebrnego ekranu Asty Nielsen oraz talent reżyserów takich jak Benjamin Christensen, a przede wszystkim Carl Theodor Dreyer, który realizował filmy przez niemal pół wieku, także w Szwecji, Francji i Niemczech. Wśród twórców szwedzkich tego pierwszego okresu najważniejsi byli Victor Sjöström i Mauritz Stiller. Szczepański poświęca im szczególną uwagę, wskazując przy tym, że już wtedy wyłoniły się cechy kina nordyckiego, które na długie lata przypisywano do jego formuły, dość wyrazistej i ponadczasowej, takie jak istotny związek z rodzimą klasyką literacka, tradycją mitologiczną i plebejską czy upodobanie do dramaturgicznego wykorzystywania malowniczego krajobrazu i przyrody z jej trudnymi warunkami klimatycznymi, co sprzyjało mrocznej tonacji filmowych opowieści. Obok tego rozwijał się oczywiście - jak wszędzie w świecie - nurt popularnego kina rozrywkowego, który z całą siłą dał o sobie znać po wprowadzeniu dźwięku. Ten wynalazek skazywał jednak kino skandynawskie na marginalizację ze względu na barierę językową - dlatego też lata 20. i 30. ocenia Szczepański jako kryzysowe, także z uwagi na naśladowczy charakter wielu powstających wtedy filmów (wzorem było kino amerykańskie klasy B) i dość powszechne wówczas tendencje eskapistyczne. Punktem kluczowym jego wywodu jest moment wejścia do branży filmowej Ingmara Bergmana. Stało się to w 1944 r., kiedy zaistniał jako scenarzysta Skandalu Alfa Sjöberga. Jest sprawą oczywistą, że Szczepańskiemu to właś- 
nie Bergman, bohater jego monumentalnej biografii pt. Zwierciadło Bergmana ${ }^{3}$, jest najbliższy, że to on będzie stałym punktem odniesienia. Patronuje on najważniejszej części tej książki - poświęconej nowofalowemu kinu skandynawskiemu - do której autor wprowadził zresztą najwięcej uzupełnień w stosunku do pierwodruku. Dla jednych Bergman był mentorem, dla innych antagonistą. Ale Szczepański wskazuje na pewien systemowy paradoks określający sytuację reżysera w ojczystym kraju, wybrzmiewający tu nawet mocniej niż we wspomnianej biografii. Jego wybitna indywidualność, talent i niewątpliwe osiągnięcia, zarówno filmowe, jak i teatralne, doceniane na całym świecie, nie zapewniały mu ani przychylności rodzimej krytyki, ani stabilizacji zawodowej i materialnej, a nawet nastręczały kłopotów ze strony władz w postaci oskarżeń o machinacje finansowe. Dopiero Fanny i Aleksander (1982), dzieło nagrodzone Oscarami i Złotym Globem, stało się dla niego świadectwem sukcesu i spełnienia artystycznego - nurtujące go od początku odwieczne problemy egzystencjalne, związane z dziedzictwem rodzinnym i kulturowym, tu udało mu się zawrzeć w absolutnie doskonałej formie filmowej.

Dwaj twórcy, Bo Widerberg i Jan Troell, jawią się w tym ujęciu jako znakomici polemiści Bergmana. Widerberga Szczepański przedstawia jako lidera antybergmanowskiego frontu w kinie szwedzkim i nowego programu artystycznego. We fragmencie cytowanej przez niego książki Wizja w szwedzkim filmie Widerberg, wówczas jeszcze reżyser amator (ale już po debiucie zrealizowanym wspólnie z Troellem, Chłopiec z latawcem), stawia mistrzowi mocny zarzut ${ }^{4}$ S Szwecja należy do najbardziej zsekularyzowanych krajów świata, ale Ingmar Bergman obstaje przy tym, by ukazywać ludzi zajmujacych się wyłacznie tym, czy Bóg istnieje, czy nie. Problem ten siła swojego ciężaru usuwa w cień wszystkie inne kwestie (s. 150). Tymczasem według niego istniała paląca potrzeba zwrócenia się w stronę zwykłych ludzi, dotknięcia doczesnego życia i realnych problemów, zwłaszcza ze strony artysty, który już osiągnął tak prestiżową pozycję. Sam Widerberg w swojej późniejszej twórczości istotnie kierował uwagę na bohaterów mocno osadzonych społecznie, aktywnych, często buntowniczych, zaangażowanych ideowo, z poczuciem sprawstwa, ale nie był doktrynerem, pozostawał wyczulony na poetycki aspekt rzeczywistości czy na jej walory wizualne. Był lewicowcem, podobnie jak Troell, któremu Szczepański poświęcił osobną książkę , uważa go bowiem za najwybitniejszego po Bergmanie szwedzkiego artystę. Znamienne, że wyższa szkoła filmowa została utworzona w Szwecji stosunkowo późno, bo w 1964 r., tak więc reżyserzy wcześniejszych generacji wywodzili się z różnych profesji. Troell był nauczycielem i zajmował się filmem amatorskim oraz fotografia, ale wiążąc się z filmem zawodowo, pragnął zachować nad nim pełną kontrolę, był autorem, operatorem i montażysta, szczególnie wyczulonym na wizualny aspekt dzieł. Istotny dla jego osobowości twórczej okazał się krytyczny stosunek do kierunku przemian dokonujących się w coraz bardziej zasobnym, sytym i egocentrycznym społeczeństwie.

U źródeł filmowych impulsów nowofalowych, jak wszędzie, były w latach 60. procesy społeczne i narastający bunt młodszych pokoleń. Szczepański zwraca jednak uwagę na niejednorodność tych zmian. W Szwecji na plan pierwszy wysuwa się polityka państwa, a zwłaszcza powstanie Szwedzkiego Instytutu Filmowego finansującego debiuty młodych, ambitnych twórców. W Danii na młode kino szczególny wpływ wywarła francuska nowa fala, ale próbowano ją łączyć z lokalnym kinem popularnym. Jednak za najciekawszy film tego okresu uchodzi Głód (1966) 
według powieści Knuta Hamsuna w reżyserii Henninga Carlsena, zrealizowany w koprodukcji z Norwegią i Szwecją. Szczepański widzi w nim pewien zamysł ideologiczny: aby z osoby Hamsuna, pisarza skompromitowanego poparciem udzielonym Hitlerowi i otoczonego przez dwie powojenne dekady kłopotliwym milczeniem, solidarnie zdjać piętno hańby. Przeniesienie na ekran książki, która jest jednym z najbardziej przenikliwych artystycznych dokumentów ludzkiej nędzy i upokorzenia - a zarazem walki o godność - (...) zakrawało na akt artystycznej prowokacji (s. 179) w ultranowoczesnym, zamożnym społeczeństwie. W Norwegii, gdzie skala dokonań nowofalowych była mniej spektakularna, Szczepański odnotowuje pojawienie się wyrazistego nurtu kobiecego reprezentowanego przez trzy reżyserki: Anję Breien, Vibeke Løkkeberg i Lailę Mikkelsen. W Finlandii wreszcie innowacyjna energia płynęła z niewielkich prywatnych wytwórni promujących przedsięwzięcia młodych artystów. Procesy te nie przebiegały w Skandynawii bezkonfliktowo. Ambicje twórcze zderzały się bowiem wszędzie z przyzwyczajeniami publiczności, która szukała w kinie czystej, bezinteresownej rozrywki. Równocześnie dokonywała się radykalna rewolucja obyczajowa, co zaowocowało rozwojem filmowej produkcji erotycznej, odważniejszej i bardziej wyrafinowanej niż w innych krajach europejskich.

Kino artystyczne wymagało jednak coraz większych środków finansowych, zwłaszcza wobec intensywnego rozwoju w latach 80. i 90. nowych mediów, telewizji satelitarnej i kablowej oraz popularności wideo, stąd coraz większa rola północnoeuropejskich działań transnarodowych, czego efektem było powstanie w Oslo Nordyckiego Funduszu Filmowego i Telewizyjnego. Szczepański stwierdza, że wycofanie się z aktywnej działalności Ingmara Bergmana osłabiło prestiż kina szwedzkiego, choć jest skłonny dostrzegać ciągłość wywodzącej się od niego tradycji filmowej i jej niesłabnącą potencję. Przywołuje tu na przykład Andrieja Tarkowskiego z jego Ofiarowaniem (1986), ale także szwedzkich twórców podejmujących wątki bergmanowskie. Innym przejawem obecności Bergmana, o niemal metafizycznym wydźwięku, była aktywność jego ulubionych aktorów, takich jak Liv Ullmann czy Max von Sydow i Ewa Fröling, a także reżyserskie dokonania operatora większości jego filmów Svena Nykvista. Również w filmach Troella, niegdysiejszego artystycznego przeciwnika Bergmana, autor dostrzega ziarno zasiane przez mistrza. Czas jednak robi swoje i pojawiają się twórcy mający zupełnie inną wizję sztuki filmowej, skierowaną do masowego odbiorcy, a zarazem przenikliwie obserwujący mechanizmy społeczne i psychologiczne oraz życie uwikłanych w nie jednostek.

Ostatni rozdział jest poświęcony filmom ostatnich lat XX w. To zamknięcie stulecia ma raczej charakter symboliczny niż faktyczny. Kryzys na trwale zagościł w refleksji nad kulturą współczesną i stał się elementem powszechnego ludzkiego doświadczenia. Sztuka nie toleruje próżni i do głosu dochodzą nowi interesujący artyści. Światowy rozgłos zyskała twórczość Duńczyka Larsa von Triera i ruch Dogma 95 oraz Szweda Lukasa Moodyssona, którego Fucking Åmål (1998) osiągnął olbrzymi sukces międzynarodowy, a także fińskie filmy braci Kaurismäki, zwłaszcza młodszego z nich, Akiego. Szczepański rzetelnie odnotowuje te zjawiska. Dostrzega tendencję do częstrzego wykorzystywania stylistyki kina popularnego nastawionego na sukces komercyjny, ale też próby nowatorskie formalnie i estetycznie, oraz te czerpiące z rodzimej, lokalnej tradycji czy - jak dawniej - z klasyki literackiej. Ta szczególna skandynawska egzotyka zyskuje również coraz częściej uznanie światowe, czego dowodem są nagrody na międzynarodowych festiwalach. 
Tom - jak zapowiada tytuł - opisuje pierwsze stulecie tej kinematografii. Minęło jednak dwadzieścia kolejnych lat i pozostaje pewien niedosyt, ponieważ wiele się przez ten czas zdarzyło. Jest nadzieja, że i o tym Tadeusz Szczepański napisze. Na okładce tomu widnieje sylwetka posępnej śmierci z Siódmej pieczęci (1958) Bergmana, złowrogie memento naszej niepewnej współczesności. Powracają niegdysiejsze lęki. Do Bergmana będziemy wracać mimo wszystko.

Tadeusz Szczepański, Kino nordyckie. Pierwsze stulecie, Wydawnictwo PWSFTviT, Łódź 2020.

1 Por. A Companion to Nordic Cinema, red. M. Hjort, U. Lindqvist, Wiley Blackwell, Hoboken 2016.

2 J. Sundholm, I. Thorsen, L. G. Andersson, O. Hedling, G. Iversen, B. T. Møller, Historical Dictionary of Scandinavian Cinema, Scarecrow Press, Plymouth 2012, s. X.
${ }^{3}$ T. Szczepański, Zwierciadło Bergmana, słowo/obraz terytoria, Gdańsk 1999.

${ }^{4}$ B. Widerberg, Visionen i svensk film, Bonnier, Stockholm 1962.

${ }^{5}$ T. Szczepański, Jan Troell, Korporacja Ha!art, Kraków 2009.

Teresa Rutkowska

\section{Bibliografia}

Hjort, M., Lindquist, U. (red.) (2016). A Companion to Nordic Cinema. Hoboken: Wiley Blackwell.

Sundholm, J., Thorsen, I., Andersson, L. G., Hedling, O., Iversen, G., Møller, B. T. (2012). Historical Dictionary of Scandinavian Cinema. Plymouth: Scarecrow Press.

Szczepański, T. (1999). Zwierciadło Bergmana. Gdańsk: słowo/obraz terytoria.

Szczepański, T. (2009). Fan Troell. Kraków: Korporacja Ha!art.

Szczepański, T. (2020). Kino nordyckie. Pierzesze stulecie. Łódź: Wydawnictwo PWSFTviT. Widerberg, B. (1962). Visionen i svensk film. Stockholm: Bonnier. 


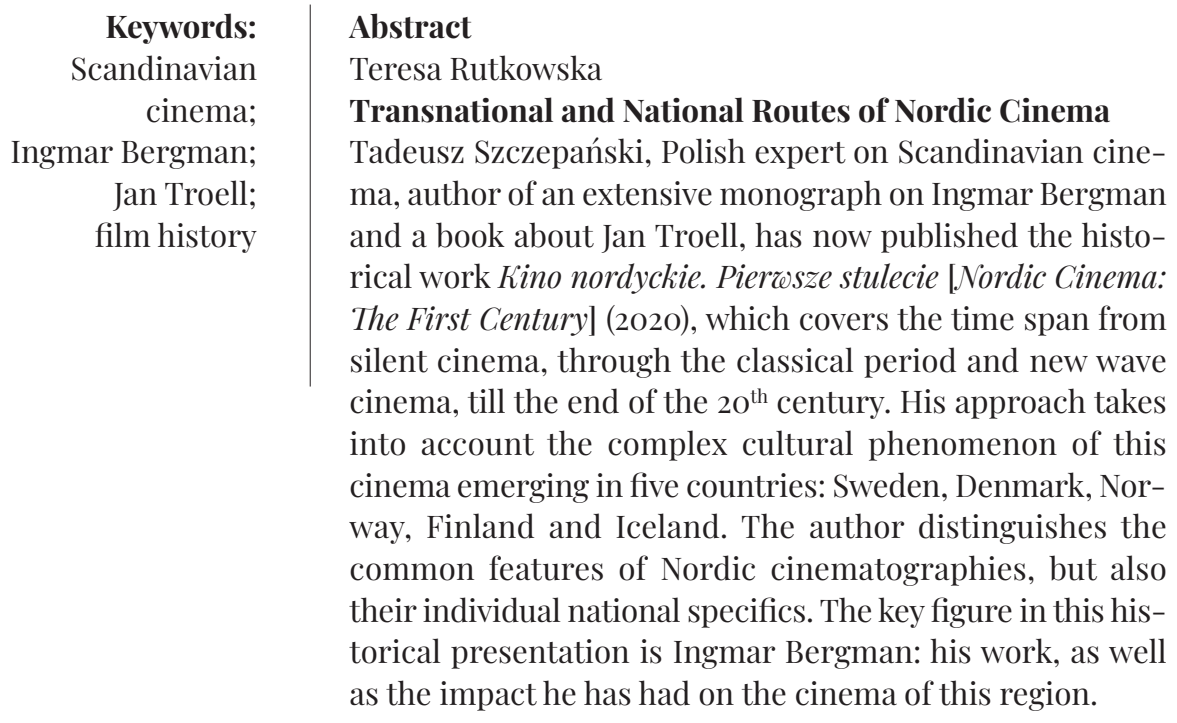

